\title{
Validity and Reliability of the Organizational Communication Satisfaction Scale for Millenial Employees in Indonesia
}

\author{
Nugroho Dwi Priyohadi \\ Faculty Psychology, Universitas Airlangga, Indonesia \\ Chairman STIAMAK Barunawati Surabaya Indonesia \\ Nugroho.dp@stiamak.ac.id
}

\section{Fajrianthi}

Faculty of Psychology, Universitas Airlangga Indonesia

Fajrianthi@psikologi.unair.ac.id

\author{
Fendy Suhariadi \\ Faculty of Psychology, Universitas Airlangga Indonesia \\ Fendy.suhariadi@psikologi.unair.ac.id

\section{Soedarmanto} \\ Faculty Administrasi Bisnis, STIAMAK Barunawati \\ Surabaya \\ soedarmanto@stiamak.ac.id
}

\begin{abstract}
This study aims to test and carry out the process of adapting the organizational communication satisfaction measurement tool of millennial employees in Indonesia. The purpose of this research is to discover suitable measurement of communication satisfaction, adjusted to the conditions in Indonesia. Confirmatory Factor Analysis (CFA) method with AMOS version 18 was used to analyzed data of 738 people who participated in the study from April to August 2019. The CFA model used to test the Communication Satisfaction instrument uses the second-order model consisting of seven dimensions: Communication Climate and Organizational Integration; Supervisory Communication; Media Quality; Horizontal (Coworker) Communication; Organizational Perspective (Corporate Information); Personal Feedback; Subordinate CommunicationThe scale was adapted from the Communication Satisfaction questionnaire developed by Down \& Hazen (1977), Down \& Adrian (2004), Okay and Okay (2009) and Wagner et al. (2014). The results show that the scale is valid for 40 items and invalid for I item. It is concluded that the adaptation process was successfully carried out, and the scale could be used for millennial employees.
\end{abstract}

Keywords:Communication satisfaction, millennial employees, scale adaption, organizational performance.

Received 2 September 2019/Accepted 30 November 2019 @JEHCP All rights reserved

\section{Introduction}

Indonesia is currently entering a new demographic era, better known as the bonus demographic era, marked by changes in the age structure of the population (Ministry of Women's empowerment \& Child Protection, 2018). Additionally, this bonus demographic era is also accompanied by the booming of the millennial generation born between 1980-1999. A study from the Boston Consulting Group (in the Ministry of Women; Empowerment \& Child Protection, 2018), stated that there are at least four main 
characteristics of the millennial generation, namely (I) interest in conventional reading is replaced by reading through smartphones, (2) nearly all millennial generation has social media as a communication device as well as source of information, (3) prefers smartphones over television as a source for entertainment, and (4) close family becomes the source of decision making.

Johnson \& Eddy (2015) recorded that there is a clear difference between the millennial and older generation; thus, the latter needs to care and understand about the Millenials' psychological dynamic. Dharmasiri\&Ranaweera (2019) stated that in terms of performance in organizations, the millennial generation has a unique approach, particularly in terms of leadership, role conflict, communication, and superior-subordinate relationship relating to interactions that could impact satisfaction or dissatisfaction.

For that reason, it becomes important for us to understand the millennial generation, especially in terms of communication within an organization (Johnson \& Eddy, 20I5). According to the data from SUSENAS, the population of the Indonesian millennial generation has roughly reached 80 million people, around $33.75 \%$ of the total population. (Ministry of Women's empowerment \& Child Protection, 2018). It is crucial to understand how millennial generation communicates in an organization. As a first step, the measurement tool to find out this aspect of communication becomes very important to obtain academic standards for research in the field of communication in organizations.

For this reason, this research will test the measurement of Communication Satisfaction on millennial generation subjects in Indonesia. According to several studies, communication satisfaction is essential because it influences the achievement of the organization's vision and mission, which incidentally is reflected in employee performance and organizational performance. Chlomoudis and Pallis (2009) say that many organizations, as industrial zones, will be increasingly complex by being operated 24 hours a day and seven days a week. This creates a very intensive communication pattern, potentially affecting individual performance. International organizations have very complex implications in terms of sociological, psychological, anthropological, and even political.

In this context, there are processes of communication, leadership, decision making, technology and scientific transfer, creativity and innovation, which, according to Bhagat and Steers (2009), cultural encounters that differ from communication patterns and managerial teams, will influence motivation, 
attitudes and individual behavior, so that it impacts on job satisfaction, teamwork, and individual performance.

Marlow and colleagues (2018) stated that communication within a team greatly influences performance. The conclusion is in accordance with the results of a meta-analysis. Gibson et al. (2012) found that the success of future management depends very much on the ability of leaders to communicate. This is related to a simple process, but in the process, it can be complicated, namely: who says what, how, to whom he conveys the message and the consequences of the communication itself. Communication in the global world has the potential to cause misunderstanding, not only because of differences in language that can lead to differences in interpretation of specific vocabulary, multi-interpretation, but also the cultural differences that are brought together by the globalization process.

Communication is defined by Gibson (2012) as "the process of transmitting or delivering information and understanding through common symbols, both verbal and nonverbal, vertical or horizontal, even crossing/ diagonally."According to Gibson et. al., (2012), dimensions in communication patterns include; (I) communicator (i.e., how effective the messenger is conveying the purpose and content of the message), (2) message (i.e., the content of the communication itself), (3) medium (i.e., what media are used, tools, and means of communication infrastructure), (4) receiver (i.e., ability to translate the message content from the message communicator, (5) feedback received between the sender and the recipient.

The present context that is relevant to the problem of communication is the process of globalization and the growing popularity of information technology. The digital age also causes online-based communication to become more prominent, so that communication is increasingly important to convey ideas, socialize policies, and stimulate perceptions of increasing achievement.

Communication patterns in an organization affect individual performance. This is evidenced by a study by Balondi. According to Balondi, companies that have excellent communication patterns are those who are effective listeners to their workers and who have proper planning. Balondi (as cited by Bhatia and Balani, 20I5) suggested that excellent internal communication makes employees work in an organized manner and improve company performance. 
Worker's productivity increases when there is communication within the organization (Hellweg \& Phillips, 1982). Among others, communication within the organization helps employees to conduct their jobs properly, to get information about the tasks they have to carry out, and about the goals of their organization. Communication within organizations also supports the achievement of effective decision making (Hellweg \& Phillips, 1982).

In this research, it is found that communication between employees as communication transactions (Smidts et al., 200I). In the study, it was concluded that employees who obtain adequate information about the activities of the organization would develop and earn achievements that can form characteristics that differentiate it from other organizations.

Communication has a solid relationship with organizational functions. Communication activities in organizations that consist of sharing knowledge and communication between members of the organization can create innovations in the organization (Monge et al., 1992). Monge et al. also found that communication activities have a substantial effect on performance outcomes in organizations. They stated that the participatory environment in organizations increases productivity and work outcomes in organizations.

The findings made by Dirks et al. show that communication that creates a trust has a direct influence on various work outcomes in organizations (Dirks et al., 200I; Elving, 2005). According to them, the belief that emerges is an essential element in the organization because it is positively related to the attitudes, perceptions, behavior, and work results of individuals in the organization.

The measuring instruments that are considered to be very effective in mapping communication conditions in organizations are the Communication Satisfaction scale (Downs \& Hanzen, 1977; Downs \& Adrian, 2004). This scale can measure communication satisfaction in organizations up to the level of individuals within the organization. Many researchers use this tool with several adaptations, for example, Goodboy, et al. (2009) who researched student's communication satisfaction, Okay and Okay (2009) who researched some Postal workers in Turkey, and also other researchres examined communication satisfaction with organizational commitment as well as developed the constructs of the Asynchronous Discussion Communication Satisfaction (Hung \& Chao, 2014). As such, testing the Communication Satisfaction 
instrument is very important, especially on the millennial generation. This conclusion is primarily because existing measurement tools have so far been aimed at employees of the organization in general, not specifically addressed to millennial employees, especially in Indonesia.

This research also becomes important as it has been done by Myers and Sadaghiani (2010), who say that communication is important to know whether individuals in the organization understand the vision or mission or not. The millennial generation, according to Myers and Sadaghiani (2010), requires intensive communication with supervisors, so the level of satisfaction with that communication needs to be known.

Research on the scale of communication is also important because, according to Johnson and Eddy (20I5), millennial workers do have different characteristics, so communication in organizations is one of the important factors for success in improving millennial performance. Thus it can be concluded that the communication satisfaction scale is important to be researched and reformulated as it has been developed by previous researchers.

\section{Method}

\section{Respondents}

This study involves as many as 738 millennial workers who are also part-time students at an institution in Surabaya. The data collection period was from April to August 2019, with the distribution of 494 male subjects and 244 female subjects. The researcher guarantees that data collection was carried out voluntarily, without pressure, and all participants filled the data with high independence. The process of data retrieval also took place willingly, without pressure, so researchers guarantee the existence of objectivity in the research of this measuring instrument test.

\section{The measurement}

The communication satisfaction adaptation of Downs \& Hanzen (I977; Downs and Adrian, 2004) consists of $4 \mathrm{I}$ items. The adaptation process is carried out with frontward translate and backward translate, namely translating the original measuring instruments into Indonesian, and then consulting with translators guaranteed to be compatible with the original edition of the measuring instrument by referring to the process of adapting questionnaire items based on statements from Epstein et al. (20I5). They argue that to 
ensure equality between the adapted and original questionnaire items, an adaptation process is needed so that their characters and functions remain analogous.

\section{Procedure}

Based on ITC (International Test Commission) Guidelines for Adaption Test (2016), the adaptation process takes place as follows: Pre-conditions Advanced Translation Initial Synthesis based on translation ---- Synthesis ----- Reverse Translation ---- Reverse Version of Synthesis --- Expert review. After an expert review, the Communication Satisfaction Scale Manuscript is ready to be completed ---- Test on 200 Subjects.

\section{Data analysis method}

Testing the questionnaire instrument is done by examining the validity and reliability of the construct (factor variables) that is checking how much the degree of the test by measuring the hypothesis that is desired to be measured (Azwar, 2003).

Constructs or variables factors are temperament variables that are not measured directly or cannot be observed, which can explain behavior. Testing the construct validity includes the hypothesis test, which is based on a theory/concept proposed forward against the construct.

Joreskog and Sorborn (1993) state the CFA method is used to test the unidimensional, validity, and reliability of the measurement model of a construct (variables facto) where the constructed variable is not measured directly. This measurement model shows the operationalization of variables or research constructs into measurable indicators that are formulated in the form of equations and/or specific path diagrams (Hair: 2010). The purpose of the CFA method is specifically to test whether it can be confirmed whether the question items in the questionnaire created are valid in explaining the construct and that the overall construct is reliable.

The stages in the CFA method are firstly testing the goodness of fits of the testing model; in other words, the suitability of the existing data with the measurement model created. Testing the relevance of the measurement model is done by comparing the statistical value with the reference value, namely Chi-square (x2) or Chi-square probability value, and Root Mean Square Error Approximation (RMSEA), Goodness of 
Fit Index (GFI), Adjusted Goodness of Fit Index (AGFI) and Comparative Fit Index. The comparison criteria that the measurement model is appropriate / model fit is if the Chi-square $(\chi 2) \leq$ Chi-square table or the Chi-square probability $\geq 0.05$; and RMSEA $\leq 0.08$; then GFI, AGFI and CFI $\geq 0.9$ (close to I).

Furthermore, if the model does not fit, then the CFA model is modified in several ways, namely by linking between error measurements by covariance or by linking between question items to other dimensions/variables according to the instructions in Lisrel (Furr, 2008; Kline, 20II). After the Goodness of Fit Test of the CFA model is appropriate (model fit), researchers proceed to examine the construct validity. Validity testing is done by looking at two values. Firstly, the value of standardized estimates (factor loading) of the questionnaire items. If an item has a factor loading value greater than 0.6 , then the items are convergently valid. As stated by Hair, et al. (2010); Ghozali, (2008), that the loading factor reference value of 0.60 or more is considered to have strong validation to explain the constructed variable (indicator variable). But there are other references (Sharma, 1996; Ferdinand, 2000) that demonstrate that the weakest loading factor that can be accepted is 0.40 or close to 0.40 .

Second, the value of unstandardized estimates (regression coefficient values) of the questionnaire items, if the value of the regression coefficient has a probability value $(P)$ of the t-statistics value smaller than aie, error tolerance of $5 \%(0.05)$. Then the question items collected have a significant effect on the construct/variable. So it can also be concluded that the question item is valid affecting the construct/variable.

Based on the two values from the validity test, a conclusion is drawn that at least one of the two is valid (convergently or significantly). It is determined that the question items are valid and fit for further use to measure the construct/variable. Whereas, if one item has a validity testing value (convergently or significantly), of the two standardized and unstandardized values is not fulfilled, then it is determined that the question item is invalid and is not feasible/eliminated further in measuring the construct/variable.

After testing the construct validity, construct reliability testing is then performed to see the overall reliability of a construct/variable in which the dimension of the question items is. Test statistics on reliability testing using Composite reliability (CR) values. According to Hair et al., (2010), Ghozali (2008), if the value of $C R \geq 0.6$, then the constructed variable concluded reliable. 


\section{Result}

CFA Testing on Dimensions of the Communication Satisfaction Construct The testing of a questionnaire is done by examining the validity and reliability of a given construct, namely by testing the degree by which the test could measure the intended hypothesis (Azwar, 2003). The observed construct or variable is a latent factor that is measured indirectly to explain behavior. The validity and reliability testing of that construct include testing the hypothesis based on a proposed theory or concept.

The validity and reliability testing of the construct was examined using the Confirmatory Factor Analysis (CFA) method.

Joreskog and Sorborn (1993) stated that the CFA method is used to test unidimensional, validity, and reliability of the measurement model of a construct (factor variable) where the construct is not measured directly. This measurement model shows the operationalization of the studied variable or constructs into measurable indicators, formulated into a specific in the form of equations and/or certain path diagrams (Hair, 2010). Specifically, CFA aims to confirm whether the questionnaire's items are valid in explaining the construct and whether the entire construct can be deemed reliable.

The first stage of CFA is to test the goodness of fit of the measurement model. In other words, the aim would be to test the conformity between existing data and the measurement model created. Testing the suitability of the measurement model is done by comparing the statistical value with the reference value, namely the value of Chi-square $(\chi 2)$ or Chi-square probability, Root Mean Square Error Approximation (RMSEA), Goodness of Fit Index (GFI), Adjusted Goodness of Fit Index (AGFI), and Comparative Fit Index. A measurement model is stated as fit (model fit) when the Chi-square value $(\chi 2)$ is lower or the same as the Chi-square table or the Chi-square probability value $\geq 0.05$; RMSEA $\leq 0.08$; GFI, AGFI and CFI $\geq 0.9$ (close to I).

Furthermore, if the model is not suitable, then the CFA model modification is carried out. This modification can be done in several ways, including by linking between error measurements by means of covariance or by linking between question items to other dimensions/variables following the instructions in Lisrel (Furr, 2008; Kline, 20II). Furthermore, when the CFA Goodness of Fit test has produced a fit 
model, a construct validity test is performed. Validity testing is done by looking at two values, namely:

First, standardized estimates (loading factor) score of the questionnaire items. If an item has a factor loading value greater than 0.6 , then it is considered convergently valid. As stated by Hair et al. (2010) and Ghozali (2008), items with a factor loading value of 0.60 or more are considered to have strong validation to explain the construct (indicator variable). Other references (Sharma, 1996; Ferdinand, 2000), however, explain that the weakest loading factor that can be accepted is 0.40 or close to 0.40 .

Second, unstandardized estimates (regression coefficient) score of the questionnaire items. If the regression coefficient value of an item has at value with a probability $(p)$ that is smaller than $\alpha$, i.e., error tolerance of $5 \%(0.05)$, then it can be concluded that the item has a significant effect on the construct/variable. In other words, the item is valid, affecting the construct/variable.

Based on the validity test, it was concluded that at least one of the two validity testing values was fulfilled (convergently or significantly), indicating that the question items were valid and worthy of being used to measure constructs/variables. Whereas if an item does not meet the standardized or unstandardized values (both convergent and significant), it can be determined that the question items are invalid and should be eliminated from being used to measure constructs/variables.

After testing the construct validity, construct reliability testing is then performed to see the overall reliability of the construct/variable through the dimensions of the items. Statistical tests on reliability testing use Composite reliability (CR) values. According to Hair et al., (2010) and Ghozali (2008), if the CR value is $\geq 0.6$, then the construct of the variable is concluded to be reliable.

\section{CFA Testing for the Communication Satisfaction Questionnaire}

Second-order CFA Testing for the Communication Satisfaction Questionnaire

As many as 738 respondents were used as samples to test the Communication Satisfaction questionnaire.

The CFA model used to test the Communication Satisfaction instrument uses a second-order model consisting of seven dimensions: Communication Climate and Organizational Integration; Supervisory Communication; Media Quality; Horizontal (Coworker) Communication; Organizational Perspective (Corporate 
Information); Personal Feedback; Subordinate Communication. Table I shows the questionnaire items for each dimension of the Communication Satisfaction construct.

Tabel I

Items from the initial questionnaire for the communication satisfaction construct

\begin{tabular}{|c|c|c|c|c|c|c|c|c|c|}
\hline \multirow{2}{*}{$\begin{array}{l}\text { No } \\
\text { I. }\end{array}$} & Dimension & \multicolumn{8}{|c|}{ Items } \\
\hline & Communication Climate and Organizational & & & & & & & & K35 \\
\hline & Integration & $\mathrm{KI} 3$ & $\mathrm{~K} 22$ & K23 & $\mathrm{K} 26$ & K28 & K29 & K32 & \\
\hline 2. & Supervisory Communication & $\mathrm{KI}$ & K7 & $\mathrm{KIO}$ & KI5 & $\mathrm{K} 16$ & $\mathrm{~K} 19$ & K36 & \\
\hline & Media Quality & $\mathrm{K} / 4$ & $\mathrm{KI}$ & K20 & K24 & K27 & & & \\
\hline 4. & Horizontal (Coworker) Communication & $\mathrm{KII}$ & $\mathrm{K} / 2$ & K3 & K3I & K39 & & & \\
\hline 5. & Organizational Perspective (Corporate & & & & & & & & \\
\hline & Information) & K40 & K2I & $\mathrm{K} 25$ & K30 & K34 & & & \\
\hline 6. & Personal Feedback & $\mathrm{K} 2$ & K6 & K33 & K38 & K4I & & & \\
\hline t. & Subordinate Communication & K4 & K9 & $\mathrm{K} 18$ & K5 & K8 & & & \\
\hline
\end{tabular}

The following shows the CFA analysis result for the dimensions of Communication Satisfaction within the questionnaire using the Analysis of Moment Structural (AMOS).

I) Goodness of Fit (GoF) analysis for the $2^{\text {nd }}$ CFA model of communication satisfaction

The GoF testing of the Communication Satisfaction CFA model was done by comparing the initial and final CFA model. The model with the most suitable GoF indec scores (model fit) will be selected. The GoF testing depicting each index of both CFA models can be viewed in the following table. 
Table 2

Comparison of the GoF index of the initial and final $2^{\text {nd }}$-order CFA model of the Communication Satisfaction Dimensions

\begin{tabular}{llllllll}
\hline Construct & Total number & & & & & & \\
of Items & $\chi^{2}$ & Prob. & RMSEA & CFI & GFI & AGFI \\
\hline Communication & Initial Model & $1452 I, 81$ & 0,000 & 0,159 & 0,406 & 0,436 & 0,372 \\
Satisfaction & Final Model & 689,12 & $0,07 \mathrm{I}$ & 0.064 & 0,864 & 0,949 & 0,874 \\
\hline
\end{tabular}

Based on the GoF index of the CFA model above; the initial CFA model scored poorly in six index criteria. On the other hand, the final CFA model showed scores that fulfilled all the criteria for a good model, namely a smaller Chi-square $\left(\chi^{2}\right)$ with a probability score over 0.05 , an RMSEA score below 0.08 , and a CFI, GFI, and AGFI value $\geq 0.09$. It can therefore be concluded that the final CFA model fits the Communication Satisfaction construct. In other words, the final CFA model is in line with the available data.

2) Validity and reliability testing of the dimensions of Communication Satisfaction

The GoF result shows that final CFA model is a fit model for explaining Communication Satisfaction. Thus, the validity and reliability testing will refer to the final CFA model. Validity testing of the dimensions of Communication Satisfaction was done by examining the factor loading score (standardized estimates) and unstandardized estimates of each item within Communication Satisfaction construct dimensions. An item is considered valid when either the standardized estimate scores more than 0.4 or the $p$-value of the unstandardized estimates scores lower than 0.05 . 
Next, reliability testing was employed by checking the composite reliability (CR). A dimension is considered reliable when it scores above 0.6 .

The detailed result of the validity and reliability testing can be viewed in the following table.

Table 3

Validity and reliability testing of the final CFA model of Communication Satisfaction

\begin{tabular}{|c|c|c|c|c|c|c|c|c|c|c|}
\hline \multirow{3}{*}{\multicolumn{2}{|c|}{ Item \& Dimension }} & \multirow{3}{*}{ Correlation } & \multirow{2}{*}{\multicolumn{2}{|c|}{$\begin{array}{l}\text { Standartized Estimates (Factor } \\
\text { Loading) }\end{array}$}} & \multirow{2}{*}{\multicolumn{3}{|c|}{$\begin{array}{c}\text { Validity Testing } \\
\text { Unstandartized Estimates } \\
\text { (Regression Coefficient) }\end{array}$}} & \multirow{3}{*}{ Conclusion } & \multicolumn{2}{|c|}{ Reliabilty Testing } \\
\hline & & & & & & & & & \multirow[t]{2}{*}{$\begin{array}{l}\text { Composite } \\
\text { Reliability }\end{array}$} & \multirow[t]{2}{*}{$\begin{array}{c}\text { Conclusio } \\
\mathrm{n}\end{array}$} \\
\hline & & & Score & Annotation & Score & $p$ & Annotation & & & \\
\hline $\begin{array}{l}\text { Communication_Cli } \\
\text { mate }\end{array}$ & $\begin{array}{l}<-- \\
-\end{array}$ & $\begin{array}{l}\text { Communication_Sa } \\
\text { tisfaction }\end{array}$ & 0.973 & Convergent & 0.314 & 0,000 & Significant & Valid & & \\
\hline $\begin{array}{l}\text { Supervisor_Commu } \\
\text { nication }\end{array}$ & $\begin{array}{l}<- \\
-\end{array}$ & $\begin{array}{l}\text { Communication_Sa } \\
\text { tisfaction }\end{array}$ & 0.894 & Convergent & 0.164 & 0,000 & Significant & Valid & & \\
\hline Media_Quality & $\begin{array}{l}<-- \\
-\end{array}$ & $\begin{array}{l}\text { Communication_Sa } \\
\text { tisfaction }\end{array}$ & 0.644 & Convergent & 0.266 & 0,000 & Significant & Valid & & \\
\hline $\begin{array}{l}\text { Cowoker_Commun } \\
\text { ication }\end{array}$ & $\begin{array}{l}<-- \\
-\end{array}$ & $\begin{array}{l}\text { Communication_Sa } \\
\text { tisfaction }\end{array}$ & 0.651 & Convergent & 0.384 & 0,000 & Significant & Valid & 0.93 & Reliable \\
\hline $\begin{array}{l}\text { Corporate_Informa } \\
\text { tion }\end{array}$ & $\begin{array}{l}<- \\
-\end{array}$ & $\begin{array}{l}\text { Communication_Sa } \\
\text { tisfaction }\end{array}$ & 0.994 & Convergent & 0.39 & 0,000 & Significant & Valid & & \\
\hline Personal_Feedback & $\begin{array}{l}<-- \\
-\end{array}$ & $\begin{array}{l}\text { Communication_Sa } \\
\text { tisfaction }\end{array}$ & 0.88 & Convergent & 0.213 & 0,000 & Significant & Valid & & \\
\hline $\begin{array}{l}\text { Subordinat_Comm } \\
\text { unication }\end{array}$ & $\begin{array}{l}<-- \\
-\end{array}$ & $\begin{array}{l}\text { Communication_Sa } \\
\text { tisfaction }\end{array}$ & 0.596 & Convergent & 0.182 & 0,000 & Significant & Valid & & \\
\hline $\mathrm{K} / 3$ & $\begin{array}{l}<-- \\
-\end{array}$ & $\begin{array}{l}\text { Communication_Cli } \\
\text { mate }\end{array}$ & 0.465 & Convergent & I & $\begin{array}{l}\text { Fix } \\
\text { paramete } \\
r\end{array}$ & Significant & Valid & 0.78 & Reliable \\
\hline K22 & $<--$ & Communication_Cli & 0.435 & Convergent & 0.813 & 0,000 & Significant & Valid & & \\
\hline
\end{tabular}


- mate

<-- Communication Cli

\begin{tabular}{|c|c|c|c|c|c|}
\hline 0.54 & Convergent & 1.263 & 0,000 & Significant & Valid \\
\hline 0.552 & Convergent & 1.578 & 0,000 & Significant & Valid \\
\hline 0,544 & Convergent & 0.946 & 0,000 & Significant & Valid \\
\hline 0.631 & Convergent & I.4II & 0,000 & Significant & Valid \\
\hline 0.578 & Convergent & 1.201 & 0,000 & Significant & Valid \\
\hline 0.655 & Convergent & 1.558 & 0,000 & Significant & Valid \\
\hline 0.281 & $\begin{array}{r}\text { Quite } \\
\text { convergent }\end{array}$ & I & $\begin{array}{l}\text { Fix } \\
\text { paramete } \\
r\end{array}$ & Significant & Valid \\
\hline 0.676 & Convergent & 3.218 & 0,000 & Significant & Valid \\
\hline 0.272 & $\begin{array}{r}\text { Quite } \\
\text { convergent }\end{array}$ & 1.076 & 0,000 & Significant & Valid \\
\hline 0.721 & Convergent & 2.747 & 0,000 & Significant & Valid \\
\hline 0.766 & Convergent & 2.94 & 0,000 & Significant & Valid \\
\hline 0.692 & Convergent & 3.048 & 0,000 & Significant & Valid \\
\hline 0.772 & Convergent & 3.339 & 0,000 & Significant & Valid \\
\hline 0.765 & Convergent & I & $\begin{array}{l}\text { Fix } \\
\text { paramete }\end{array}$ & Significant & Valid \\
\hline
\end{tabular}

0.8I Reliable

$\mathrm{KI} 6$

<-- Communication_Cli

- mate

<-- Communication $\mathrm{Cli}$

Communication

- mate

$<-$ Communication $\mathrm{Cli}$

- mate

<-- Communication_Cli

- mate

<-- Supervisor_Commu

nication

<-- Supervisor_Commu

nication

<-- Supervisor Commu

- nication

<-- Supervisor_Commu

- nication

<-- Supervisor Commu

nication

<-- Supervisor_Commu

nication

<-- Supervisor_Commu

nication

-- Media_Quality

paramete

Valid 


\begin{tabular}{|c|c|c|c|c|c|c|c|c|}
\hline $\mathrm{K} 17$ & $\begin{array}{l}<-- \\
-\end{array}$ & Media_Quality & 0.454 & Convergent & 0.82 & 0,000 & Significant & Valid \\
\hline $\mathrm{K} 20$ & $\begin{array}{l}<- \\
-\end{array}$ & Media_Quality & 0.65 & Convergent & 1.114 & 0,000 & Significant & Valid \\
\hline K24 & $\begin{array}{l}<- \\
-\end{array}$ & Media_Quality & 0.685 & Convergent & 1.065 & 0,000 & Significant & Valid \\
\hline K27 & $\begin{array}{l}<-- \\
-\end{array}$ & Media_Quality & 0.435 & Convergent & 0.502 & 0,000 & Significant & Valid \\
\hline K3 & $\begin{array}{l}<-- \\
-\end{array}$ & $\begin{array}{l}\text { Coworker_Commu } \\
\text { nication }\end{array}$ & 0.881 & Convergent & 1 & $\begin{array}{l}\text { Fix } \\
\text { paramete } \\
r\end{array}$ & Significant & Valid \\
\hline KII & $\begin{array}{l}<-- \\
-\end{array}$ & $\begin{array}{l}\text { Coworker_Com } \\
\text { munication }\end{array}$ & -0.01 & $\begin{array}{r}\text { Not } \\
\text { convergent }\end{array}$ & -0.018 & $0.8 I$ & $\begin{array}{c}\text { Not } \\
\text { Significant }\end{array}$ & $\begin{array}{l}\text { Tidak } \\
\text { valid }\end{array}$ \\
\hline $\mathrm{K} / 2$ & $\begin{array}{l}<-- \\
-\end{array}$ & $\begin{array}{l}\text { Coworker_Commu } \\
\text { nication }\end{array}$ & 0.25 & $\begin{array}{r}\text { Quite } \\
\text { convergent }\end{array}$ & 0.293 & 0.000 & Significant & Valid \\
\hline K3I & $\begin{array}{l}<- \\
-\end{array}$ & $\begin{array}{l}\text { Coworker_Commu } \\
\text { nication }\end{array}$ & 0.364 & Convergent & 0.384 & 0.000 & Significant & Valid \\
\hline K39 & $\begin{array}{l}<-- \\
-\end{array}$ & $\begin{array}{l}\text { Coworker_Commu } \\
\text { nication }\end{array}$ & 0.325 & Convergent & 0.409 & 0.000 & Significant & Valid \\
\hline K2I & $\begin{array}{l}<- \\
-\end{array}$ & $\begin{array}{l}\text { Corporate_Informa } \\
\text { tion }\end{array}$ & 0.602 & Convergent & I & 0.000 & Significant & Valid \\
\hline K25 & $\begin{array}{l}<- \\
-\end{array}$ & $\begin{array}{l}\text { Corporate_Informa } \\
\text { tion }\end{array}$ & 0.427 & Convergent & 0.87 & 0.000 & Significant & Valid \\
\hline K30 & $\begin{array}{l}<-- \\
-\end{array}$ & $\begin{array}{l}\text { Corporate_Informa } \\
\text { tion }\end{array}$ & 0.485 & Convergent & 1.001 & 0.000 & Significant & Valid \\
\hline K40 & $\begin{array}{l}<-- \\
-\end{array}$ & $\begin{array}{l}\text { Corporate_Informa } \\
\text { tion }\end{array}$ & 0.502 & Convergent & 1.016 & 0.000 & Significant & Valid \\
\hline K34 & $\begin{array}{l}<- \\
-\end{array}$ & $\begin{array}{l}\text { Corporate_Informa } \\
\text { tion }\end{array}$ & 0.538 & Convergent & 0.88 & 0.000 & Significant & Valid \\
\hline
\end{tabular}




\begin{tabular}{|c|c|c|c|c|c|c|c|c|c|c|}
\hline K2 & $\begin{array}{l}<- \\
-\end{array}$ & Personal_Feedback & 0.387 & Convergent & I & 0.000 & Significant & Valid & & \\
\hline K6 & $\begin{array}{l}<- \\
-\end{array}$ & Personal_Feedback & 0.408 & Convergent & 1.304 & 0.000 & Significant & Valid & & \\
\hline K33 & $\begin{array}{l}<- \\
-\end{array}$ & Personal_Feedback & 0.881 & Convergent & 2.784 & 0.000 & Significant & Valid & 0.69 & Reliable \\
\hline K38 & $\begin{array}{l}<- \\
-\end{array}$ & Personal_Feedback & 0.628 & Convergent & 1.934 & 0.000 & Significant & Valid & & \\
\hline K4I & $\begin{array}{l}<- \\
-\end{array}$ & Personal_Feedback & 0.43 & Convergent & 1.596 & 0.000 & Significant & Valid & & \\
\hline K4 & $\begin{array}{l}<- \\
-\end{array}$ & $\begin{array}{l}\text { Subordinate_Com } \\
\text { munication }\end{array}$ & 0.513 & Convergent & 1 & $\begin{array}{l}\text { Fix } \\
\text { paramete } \\
r\end{array}$ & Significant & Valid & & \\
\hline K5 & $\begin{array}{l}<- \\
-\end{array}$ & $\begin{array}{l}\text { Subordinate_Com } \\
\text { munication }\end{array}$ & 0.363 & Convergent & 0.707 & 0.000 & Significant & Valid & & \\
\hline K8 & $\begin{array}{l}<- \\
-\end{array}$ & $\begin{array}{l}\text { Subordinate_Com } \\
\text { munication }\end{array}$ & 0.604 & Convergent & 1.175 & 0.000 & Significant & Valid & 0.61 & Reliable \\
\hline K9 & $\begin{array}{l}<-- \\
-\end{array}$ & $\begin{array}{l}\text { Subordinate_Com } \\
\text { munication }\end{array}$ & 0.754 & Convergent & 1.772 & 0.000 & Significant & Valid & & \\
\hline $\mathrm{K} / 8$ & $\begin{array}{l}<-- \\
-\end{array}$ & $\begin{array}{l}\text { Subordinate_Com } \\
\text { munication }\end{array}$ & 0.177 & Not convergent & 0.399 & 0.000 & Significant & Valid & & \\
\hline
\end{tabular}


Table 3 shows that all the items, excluding $\mathrm{KII}$ in the co-worker communication dimension which is neither convergent nor significant, was found to be valid. As a result, the coworker communication dimension was also found to be not reliable because the composite reliability scores below 0.6. Meanwhile, other dimensions were reliable because their composite reliability scores greater than 0.6 . Table 4 depicts the valid and invalid items for each dimension in the Communication Satisfaction second-order model.

Table 4

Valid and Invalid Items for the Communication Satisfaction Construct

\begin{tabular}{|c|c|c|c|c|c|c|c|c|c|c|}
\hline No & Dimension & & & & Valid & ms & & & & Invalid Items \\
\hline I. & $\begin{array}{l}\text { Communication Climate } \\
\text { and Organizational } \\
\text { Integration }\end{array}$ & $\begin{array}{c}\mathrm{KI} \\
3\end{array}$ & K22 & $\mathrm{K} 23$ & $\mathrm{~K} 26$ & $\begin{array}{c}\mathrm{K} 2 \\
8\end{array}$ & $\begin{array}{c}\mathrm{K} 2 \\
9\end{array}$ & $\begin{array}{c}\mathrm{K} 3 \\
2\end{array}$ & K35 & - \\
\hline 2. & $\begin{array}{l}\text { Supervisory } \\
\text { Communication }\end{array}$ & $\mathrm{KI}$ & K7 & $\mathrm{K} 10$ & KI5 & $\begin{array}{c}K I \\
6\end{array}$ & $\begin{array}{c}\mathrm{KI} \\
9\end{array}$ & $\begin{array}{c}K 3 \\
6\end{array}$ & & - \\
\hline 3. & Media Quality & $\begin{array}{c}\mathrm{KI} \\
4\end{array}$ & KI7 & $\mathrm{K} 20$ & K24 & $\begin{array}{c}\mathrm{K} 2 \\
7\end{array}$ & & & & - \\
\hline 4. & $\begin{array}{l}\text { Horizontal (Coworker) } \\
\text { Communication }\end{array}$ & & $\mathrm{K} / 2$ & K3 & K3I & $\begin{array}{c}\mathrm{K} 3 \\
9\end{array}$ & & & & KII \\
\hline 5. & $\begin{array}{l}\text { Organizational } \\
\text { Perspective (Corporate } \\
\text { Information) }\end{array}$ & $\begin{array}{c}\text { K4 } \\
0\end{array}$ & K2I & K25 & K30 & $\begin{array}{c}K 3 \\
4\end{array}$ & & & & - \\
\hline 6. & Personal Feedback & K2 & K6 & K33 & K38 & $\begin{array}{c}\text { K4 } \\
\text { I }\end{array}$ & & & & - \\
\hline 7. & $\begin{array}{l}\text { Subordinate } \\
\text { Communication }\end{array}$ & K4 & K9 & $\mathrm{K} 18$ & K5 & $\mathrm{K} 8$ & & & & - \\
\hline
\end{tabular}


Figure I. The second-order CFA Model of the Communication Satisfaction construct, Standardized Estimates:

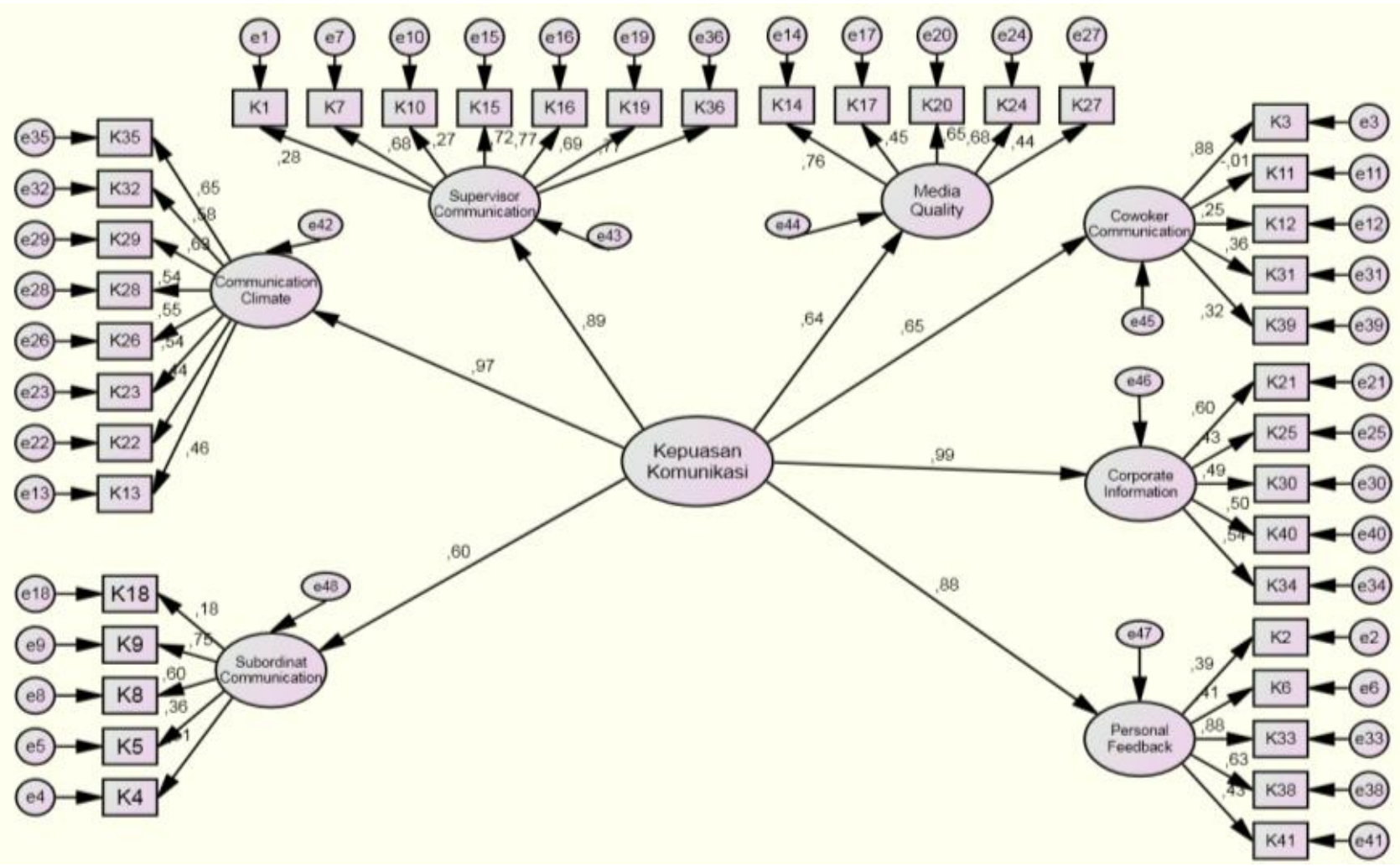




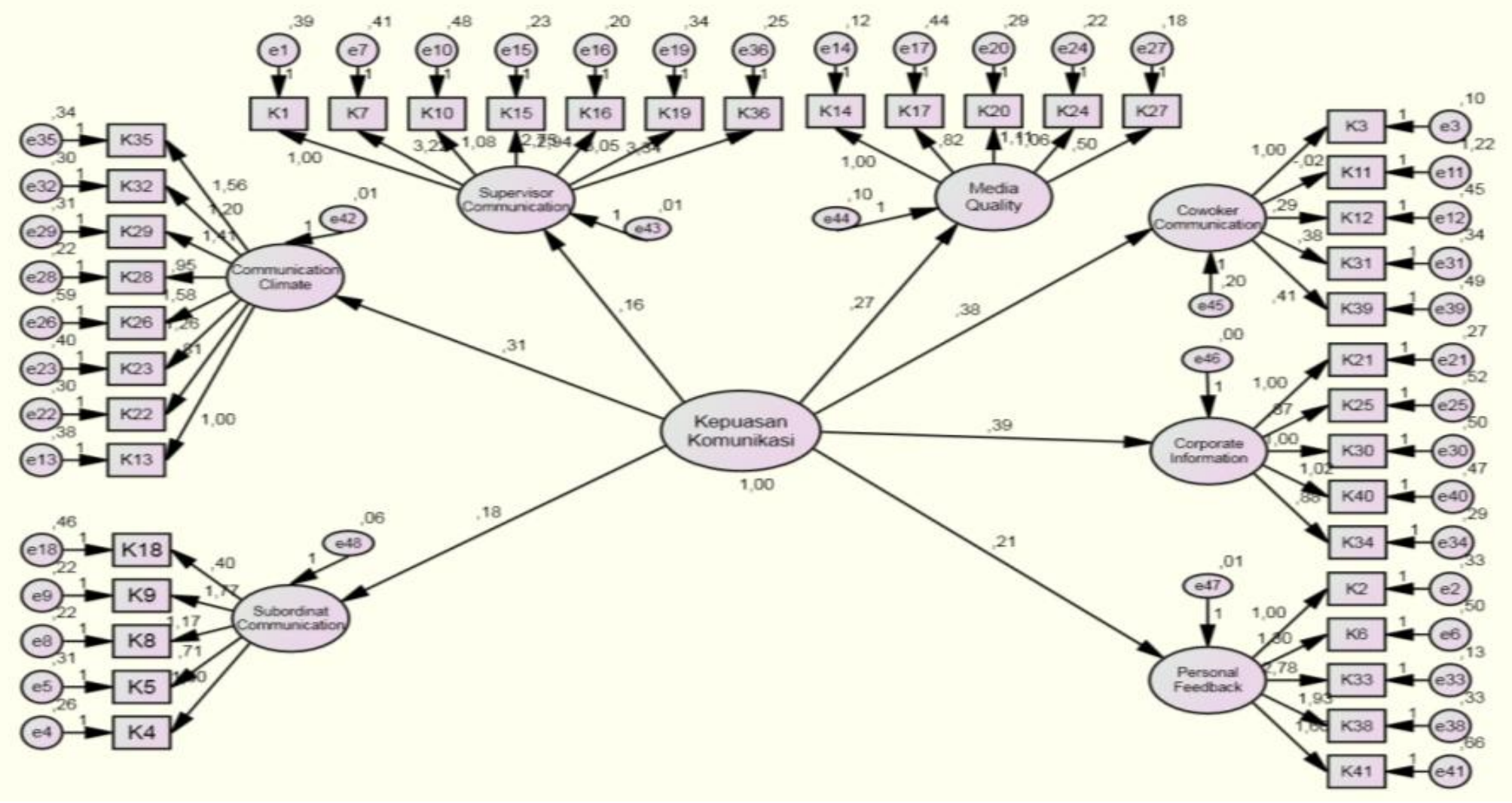

Figure 2. The Second-Order Unstandardized Estimates 


\section{Discussion}

This study successfully tested the communication satisfaction measurement tool developed by Downd\& Hazen (1977) and Clampits and Downs (1993), Dows and Adrian (2004), and Yau (2013). Research can answer the need for appropriate measuring tools to see communication satisfaction in organizations. Gibson et al. (2012) say that a comprehensive understanding of communication will significantly affect the achievement of the vision mission or goals of the organization.

Moreover, Ranaweera and Dharmasiri (2019) said that excellent communication between management and employees, especially millennial employees or also known as Generation $Y$, will improve organizational performance because employees are willing to be motivated to work for achievement. Priyohadi, Suhariadi, and Fajrianthi (2019) note that millennial employees are, on the one hand, accused of being employees who find it challenging to communicate with their seniors. Still, on the other hand, they have a fighting spirit and achievements that can be optimized in the organization. The communication factor, in this case, is essential to optimize millennial generation performance (Neves \& Eisenberg, in Ranaweera \& Dharmasiri, 2019).

The measurement test also supports the views of Myers and Sadaghiani (Ranaweera \& Dharmasiri, 2019), which stated that millennial employees could show optimal performance when there is openness, socialization, and communication of company values that are internalized by the employees. This makes it easier for employees to find similar perceptions between employees, supervisors, and management over others. Sometimes seniors feel not respected, so this communication factor will be able to reduce counterproductive actions either committed by millennial employees or even senior employees who have failed to receive communication messages from millennials (Myiers \& Sadaghiani, in Ranaweera \& Dharmasiri, 2019)

The limitation of this study and which can be followed up by other researchers is related to the diversity of respondents, such as in terms of gender differences, cultural roots, and other diversity that generally exists in Indonesia. Adaptation of the measuring instrument was successfully carried out, but it is necessary to consider other variables or factors that could be more scrutinized for further research. 


\section{Conclusion}

According to the above analysis, it can be concluded that the Communication Satisfaction measurement tool can be used validly and reliably by adjusting the item from $4 \mathrm{I}$ to 40 , by not changing the dimensions of the previous measuring device. By paying attention to the weaknesses in this study, it is suggested that the tool is still possible to be further developed by paying more attention to cultural factors, gender, digital or nondigital communication media, ethnic background, possibly becoming more attractive for the cultural diversity in Indonesia. However, as a measurement of Communication Satisfaction, this tool can still be used with the subject of millennial generation employees in Indonesia, as tested by researchers on 738 millennial participants in Surabaya.

\section{References}

Anderson, N., Ones, D.S., Sinangil, H.K., \&Viswesvaran, C., (200I), Handbook of industrial, work, \& organizational psychology, Vol. 2: Organizational psychology, London: SAGE Publications, Ltd.

Armstrong, M., (2009), Armstrong's handbook of performance management, An evidence-based guide to delivering high performance, London: Kogan Page Limited.

Avolio, B. J. (2004). Examining the full range model of leadership: Looking back to transform forward. In Leader development for transforming organizations (Pp. 9I-II8). Psychology Press.

Avolio, B. J., \& Bass, B. M. (2004). Multifactor leadership questionnaire (MLQ). Mind Garden, 29.

Azwar, Saifuddin. (2003). Metodepenelitian. Yogyakarta: PustakaPelajar

Baron, R.A \&Branscombe, N.R. (2013) Social psychology. Boston: Pearson Education Inc.

Berghe. J.V. (20I I). Job satisfaction and job performance in the workplace. Arcada: Thesis.

Bernandin, HJ.,\& Russel, J.A., (1998), Human resources management, New York: McGraw Hil. Inc.

Betts, A. (2013). Survival migration: Failed governance and the crisis of displacement. Cornell University Press.

Bhagat, R. S., \& Steers, R. M. (2009), Cambridge handbook of culture, organizations, dan work, Cambridge: Cambridge University Press 
Bhatia, K., \&Balani, M. (20I5). Effective internal communication: A crucial factor affecting employee performance. In Proceedings of International Conference on Management, Economics and Social Sciences, Dubai (pp. 135-142).

Chlomoudis, C.I., \& Pallis, A.A., (2009), The need for a new philosophy of port management and organization: Effective responses to contemporary challenges, European Research Studies, Volume 2 No. (2), pp 91 - 103.

Clampitt, P. G., \& Downs, C. W. (1993). Employee perceptions of the relationship between communication and productivity: A field study. The Journal of Business Communication (I973), 30(I), 5-28.

Dirks, K. T., \&Ferrin, D. L. (200I). The role of trust in organizational settings. Journal Organization Science, I2(4), 450-467.

Downs, C. W., \& Hazen, M. D. (1977). A factor analytic study of communication satisfaction. The Journal of Business Communication (1973), 14(3), 63-73.

Downs, C. W., \& Adrian, A. D. (2004). Assessing organizational communication: Strategic communication audits. New York: Guilford Press.

Eddy S.W.Ng., \& Johnson, J.M., (2015). Millennials: Who are they? How are they different, and why should we care? Retrieved from :

https://www.researchgate.net/publication/282368010_Millennials_Who_are they ho w_are they different_and_why should_we care.

Epstein, J., Santo, R. M., \& Guillemin, F. (20I5). A review of guidelines for crossCultural adaptation of questionnaires could not bring out a consensus. Journal of Clinical Epidemiology, 68(4), 435-44I

Ferdinand, A. (2000). Structural equation modelling dalampenelitianmanajemen. BadanPenerbitUniversitasDiponegoro. Semarang.

Furr, R. M. (2008). A framework for profile similarity: Integrating similarity, normativeness, and distinctiveness. Journal of Personality, 76(5), I267-I 3 I6.

Gibson, J., McKenzie, J., McHarg, K., Shakespeare, J., Price, J., \& Gray, R. (2009). A systematic review of studies validating the Edinburgh Postnatal Depression Scale in antepartum and postpartum women. Journal ActaPsychiatricaScandinavica, II 9(5), 350-364.

Gibson, J.L., Ivancevich, J.M., Donnely Jr, J.H., and Konopaske, R., (2012), Organizations, behavior, structure, processes, I4th Edition, New York: McGraw Hill Irwin.

Ghozali, I. (2008). Structural equation modelling, Edisi II, Universitas Diponegoro, Semarang.

Goodboy, A. K., Martin, M. M., \&Bolkan, S. (2009). The development and validation of the student communication satisfaction scale. Journal Communication Education, 58(3), 372-396. 
Hair, J.F., Black, W.C., Babin, B.J., \& Anderson, R.E. (20I0). Multivariate data analysis. Seventh Edition.New Jersey: Prentice-Hall, Upper Saddle River.

Hecht, M. L. (1978). Hecht. Michael L. Measures of communication satisfaction.journal of Human Communication Research, 4(4), 350-363.

Hellweg, S. A., \& Phillips, S. L. (1982). Communication and productivity in organizations.Journal of Public Productivity Review, 276-288.

Hung, ML. \& Chou, C. (20I4). The Development, Validity, and Reliability of Communication Satisfaction in an Online Asynchronous Discussion Scale. Journal Asia-Pacific Edu Res ne 2014, Volume 23, Issue 2, pp 165-177.

https://doi.org/10.1007/s40299-013-0094-9

Joreskog, K. and Sorbom, D. (1993) LISREL 8: Structural equation modeling with the SIMPLIS Command Language. Scientific Software Intenational Inc., Chicago.

Joreskog, K. G., \&Sorbom. (1993). Statistical analysis of sets of congeneric tests. Journal Psychometrika, 36(2), 109-133.

KementrianPemberdayaanPerempuandanPerlindunganAnak., (2018). ProfilGenerasiMilenia Indonesia. Jakarta: Kementrian PPPA

Kline R. B., (201 I) Principle and practice of structural equation modeling. 3rd ed. New York: The Guilford Press

Marlow, S. L., Lacerenza, C. N., Paoletti, J., Burke, C. S., \& Salas, E. (2018). Does team communication represent a one-size-fits-all approach?: A meta-analysis of team communication and performance. Journal Organizational Behavior and Human Decision Processes, I44, I45-I 70.

Monge, P. R., Cozzens, M. D., \& Contractor, N. S. (1992). Communication and motivational predictors of the dynamics of organizational innovation. Journal Organization Science, 3 (2), 250-274. https://doi.org//0.1287/orsc.3.2.250.

Myers, K.K., \&Sadaghiani, K. (2010). Millennials in the workplace: A Communication Perspective on Millenials's Organizational Relationship and Performance. Journal Bus Psychol. 2010 Jun; 25(2): 225-238. Published online 2010 Mar 5. DOI: I0.1007/s 10869-010-9|72-7

Okay, A., and Okay, A. (2009). An Analytic study of communication satisfaction in The Turkish Postal Service. Selçuk letișim, 6, I, 2009. (5I-66)

Retrieved from : https://dergipark.org.tr/en/download/article-file/I 77854

Priyohadi, N.D., Suhariadi, F., \&Fajrianthi. (2019). Validity Test for Short Grit Scale (Grit -S) Duckworth on Indonesian Millennials, Journal of educational, Health and Community PsychologyVol 8, No3, 2019 retrieved from :

https://www.researchgate.net/publication/33624287I_Validity_Test for_Short_Grit Scale_Grit_S_Duckworth_on_Indonesian_Millennials 
Ranaweera, C., \& Dharmasiri, A. (2019). Generation $Y$ and their job performance.Srilankan Journal of Management, 2(I), 89-99. Retrieved from : https://www.researchgate.net/publication/330358965_Generation_Y and Their_Job Performance

Smidts, A., Pruyn, A. T. H. \& Van Riel, C. B. (200I). The impact of employee communication and perceived external prestige on organizational identification. Academy of Management Journal, 44(5), 105I-1062.

\section{Lampiran}

\section{ALAT UKUR KEPUASAN KOMUNIKASI}

\begin{tabular}{|c|c|c|c|c|c|c|}
\hline No. & Pernyataan & $\begin{array}{l}\text { Sangat } \\
\text { Setuju }\end{array}$ & Setuju & Ragu & $\begin{array}{l}\text { Tidak } \\
\text { Setuju }\end{array}$ & $\begin{array}{l}\text { Sangat } \\
\text { Tidak } \\
\text { Setuju }\end{array}$ \\
\hline $\mathbf{K I}$ & Atasan saya mempercayai saya & & & & & \\
\hline $\mathbf{K 2}$ & $\begin{array}{l}\text { Pengawasan yang diberikan pada } \\
\text { saya sudah cukup tepat }\end{array}$ & & & & & \\
\hline $\mathbf{K} 3$ & $\begin{array}{l}\text { Kelompok kerja saya telah sesuai } \\
\text { Karyawan tanggap terhadap }\end{array}$ & & & & & \\
\hline K4 & $\begin{array}{l}\text { komunikasi yang disampaikan } \\
\text { atasan }\end{array}$ & & & & & \\
\hline $\mathbf{K 5}$ & $\begin{array}{l}\text { Anak buah dapat menerima } \\
\text { evaluasi, saran dan kritik atasan }\end{array}$ & & & & & \\
\hline K6 & Saya puas terhadap pekerjaan saya & & & & & \\
\hline K7 & $\begin{array}{l}\text { Atasan terbuka terhadap ide } \\
\text { bawahan }\end{array}$ & & & & & \\
\hline K8 & $\begin{array}{l}\text { Anak buah merasa bertanggung } \\
\text { jawab untuk menyampaikan inisiatif } \\
\text { ke atasan }\end{array}$ & & & & & \\
\hline K9 & $\begin{array}{l}\text { Anak buah dapat mengantisipasi } \\
\text { kebutuhan informasi saya }\end{array}$ & & & & & \\
\hline KIO & $\begin{array}{l}\text { Tersedia informasi mengenai } \\
\text { kesejahteraan pegawai }\end{array}$ & & & & & \\
\hline $\mathbf{K} \mathbf{I}$ & $\begin{array}{l}\text { Terdapat aktivitas gossip dalam } \\
\text { organisasi kami }\end{array}$ & & & & & \\
\hline $\mathbf{K} \mathbf{2}$ & $\begin{array}{l}\text { Komunikasi antar karyawan } \\
\text { berjalan akurat dan bebas }\end{array}$ & & & & & \\
\hline$K / 3$ & Tersedia informasi tentang & & & & & \\
\hline
\end{tabular}


persyaratan jabatan saya

KI4 Perintah dan laporan tertulis jelas, sigkat dan padat

KI5 Atasan mendengar dan memperhatikan saya

Atasan memberikan bimbingan

KI6 terkait pemecahan masalah dalam pekerjaan saya

Pada kondisi darurat cara

KI7 komunikasi dapat disesuaikan dengan keadaan

KI8 Atasan tidak berlebihan dalam
menyampaikan informasi
KI9 denmasi yang diperlukan terkait
Kongan pekerjaan saya, tersedia tepat waktu

K20

Komunikasi informal berlangsung aktif dan akurat

K2 I

Tersedia informasi terkait kebijakan dan tujuan perusahaan Sikap karyawan terhadap

K22 komunikasi di perusahaan positif dan sehat Tersedia informasi mengenai

K23 kebijakan divisi dan tujuan masingmasing departemen

K24 Pertemuan-pertemuan terorganisasir dengan baik, jelas dan singkat

K25 Tersedia informasi mengenai laba dan posisi perusahaan

K26 Tersedia berita mengenai pegawai

K27 Publikasi perusahaan menarik dan berguna

K28 Muatan komunikasi dalam perusahaan sudah cukup tepat Pegawai di perusahaan saya

K29 memiliki kemampuan komunikasi yang baik

K30 Tersedia informasi tentang kegagalan dan prestasi perusahaan

K3 I Konflik diselesaikan dengan cara yang tepat melalui saluran 
komunikasi yang sesuai

Komunikasi dalam perusahaan ini

K32 membuat saya merasa menjadi

bagian penting dari perusahaan

Tersedia informasi tentang

K33 perkembangan saya dalam

melaksanakan pekerjaan

K34 Tersedia informasi tentang

perubahan dalam perusahaan

Komunikasi dalam perusahaan

K35 memotivasi dan membangkitkan

semangat mencapai tujuan

K36 Atasan mengetahui dan memahami masalah yang dihadapi anak buah

K37 Usaha-usaha saya dihargai

K38 Tersedia informasi tentang bagaimana saya dinilai

Tersedia laporan tentang

K39 bagaimana penanganan masalah di bagian saya

Informasi tentang tindakan

K40 pemerintah berpengaruh terhadap perusahaan saya

Tersedia informasi tentang

K4I bagaimana pekerjaan saya dibandingkan dengan orang lain 